\title{
The Potential of Blue Carbon Stocks and Carbon Dioxide Absorption in Mangrove Forests to Support Low Carbon Emission Development in Southeast Sulawesi Province, Indonesia
}

\author{
Lies Indriyani ${ }^{\mathrm{a}, 1}$, Sahindomi Bana ${ }^{\mathrm{b}}$, Asramid Yasin ${ }^{\mathrm{a}}$, La Baco Sudia ${ }^{\mathrm{a}}$, Kahirun ${ }^{\mathrm{a}}$, La Ode Midi ${ }^{\mathrm{a}}, \operatorname{Hardin}^{\mathrm{a}}$ \\ ${ }^{a}$ Department of Environmental Science, Universitas Halu Oleo, Kendari, 93121, Indonesia \\ E-mail: ${ }^{1}$ lies.said@gmail.com \\ ${ }^{b}$ Department of Forestry, Universitas Halu Oleo, Kendari, 93121, Indonesia \\ E-mail:omiesoil@gmail.com
}

\begin{abstract}
Indonesia is a country with the second-longest coastline globally and has the most extensive mangrove forests in the world. Mangrove forests are included in the blue carbon group, which per hectare store up to four times more carbon storage than tropical forests. Mangrove forests play an essential role in absorbing carbon emissions in the air and storing a lot of carbon compared to natural forests. This study aims to determine carbon storage and $\mathrm{CO}_{2}$ absorption in mangrove forests in Kabaena Barat Subdistrict, Bombana Regency. The data comes from direct measurements in the field, namely above-ground carbon, carried out without damaging trees, only covering carbon in tree vegetation. It is the largest proportion of carbon storage on land. The data collection used a survey method to identify mangrove species, circumference, tree trunk diameter at breast height (dbh), biomass, carbon storage, $\mathrm{CO}_{2}$ absorption, and 22 plots of plotted line method with eight transects. The results showed that 10 types of mangrove species were found on the transect observation, namely Avicennia alba, Avicennia marina, Avicennia lanata, Avicennia sp., Bruguiera cylindrica, Bruguiera gymnorhiza, Rhizophora apiculata, Rhizophora mucronata, Sonneratia alba, and Xylocarpus granatum. With the total amount of biomass stored in Kabaena Barat Subdistrict's mangrove forests, Bombana Regency, is 6,664.93 tons ha ${ }^{-1}$ with carbon storage of 3,065.85 tons $\mathrm{ha}^{-1}$ and carbon dioxide absorption of 11,241.55 tons $\mathrm{ha}^{-1}$.
\end{abstract}

Keywords — blue carbon stocks; carbon dioxide absorption; mangrove forests; Kabaena.

\section{INTRODUCTION}

Global warming has become a hot topic to be discussed, even in the international arena. Although there is also a natural cause, no one doubts that the greenhouse gases released into the atmosphere in human activities through the burning of fossil fuels in the transportation, industrial, and household sectors also cause global warming and climate change. Global warming and climate change are already being felt, and there are already visible signs. For example, melting ice in polar regions, rising sea levels, changing weather patterns erratically, and so on [1].

The increase in the earth's surface temperature due to the pollution of greenhouse gases is carbon, which causes a global warming phenomenon that affects global climate change. The value of mangrove ecosystems for humans is substantial, one of which is a natural carbon sink [2]. Mangrove forests have the same role as other forests to absorb carbon dioxide $\left(\mathrm{CO}_{2}\right)$ to help prevent climate change [3].
Mangroves are extraordinary ecosystems, providing many goods and services for humans. This mainly includes pollution reduction and carbon sequestration [4]. The mangrove forest is a coastal ecosystem that plays an essential role in global climate change. Forest biomass has a relevant relationship with global warming. Forest biomass plays a critical role in the biogeochemical cycle, especially in the carbon cycle. About $50 \%$ of all carbon is stored in forest vegetation [5]. One way to control climate change is by reducing greenhouse gas emissions by maintaining natural forests' integrity and increasing tree populations' density outside the forest. Forests will be a source of greenhouse gas emissions when they are not appropriately managed [6].

Indonesia is a country with the second-longest coastline globally and has the largest mangrove forests in the world. Besides, Indonesia also has a high diversity of mangrove vegetation types, where 61 types of mangrove vegetation types of tree species are identified in Indonesia. Mangroves are included in the blue carbon group, along with seagrass 
beds and coral reefs. Mangrove deforestation is one of the fastest globally, with a 30-50 \% reduction in mangrove area in the last 50 years. Due to the degradation and deforestation of mangrove forests, $2 \%$ of mangrove carbon's long-term global storage has been released back into the atmosphere [7]. Thus, the rate of loss of carbon potential is also very large considering that mangroves store carbon 5 times greater than tropical rainforests [8]. The potential for carbon sequestration in coastal vegetation is also quite significant (up to $77 \%$ ) compared to terrestrial vegetation [9]. Mangrove forests cover less than $1 \%$ of tropical forest areas. Still, they can capture around $24 \mathrm{Tg} \mathrm{C} /$ year of carbon because of their high productivity, representing about $3 \%$ of the total global tropical forest carbon capture [10].

The capture and storage capacity of mangrove forest carbon worldwide varies significantly from geomorphic variables and biophysical variables [11]. Carbon stocks in mangrove forests also go with tidal inundation gradients that affect species composition and productivity [12]. Mangrove forests in Indonesia have great potential to absorb $\mathrm{CO} 2$ from the atmosphere and store it in body biomass. This can be seen from the area of mangrove forests in Indonesia, which reaches $22.4 \%$ of the world's mangrove area or around 3.22 million hectares [13]; [14]; [15]. This area is much higher than Brazil and Australia, which each has a proportion of \pm $7 \%$ of global mangroves. The highest distribution of mangroves in Indonesia is found in the Papua Islands (West Papua and Papua Provinces), almost half of the national mangrove area [15]; [16].

The diameter of the stand itself influences the value of biomass. This is because the larger the diameter of a tree, the greater the biomass value will be. In proportion to the effect of diameter, stand height will also increase the biomass value. As the mangrove stands grow, it will produce a large value of biomass and stored carbon. This phenomenon is caused by the photosynthetic process, which absorbs $\mathrm{CO}_{2}$ from the atmosphere allocated to leaves, twigs, stems, and roots as growth support [17]. Indonesia's mangrove forests can store more than 3.14 billion metric tons of carbon [18] than all other forests on earth. Maintaining one hectare of mangrove per year can contribute to absorbing 52.85 tons of $\mathrm{CO}_{2}$ carbon. The ability of coastal vegetation to absorb carbon is an essential ecosystem service, especially in the era of global climate change [19]. It is necessary to estimate mangrove aboveground biomass on a large scale to understand their role in climate change mitigation efforts [20].

Population growth and urbanization in coastal areas are higher than in other areas [21]. This requires an increase in infrastructure development to support human life activities, one example is reclamation as a form of land-use change. However, this land-use conversion activity is generally carried out at the expense of the existence of coastal ecosystems such as mangroves. Exploitation and inadequate management resulted in a decrease in the area of coastal vegetation, which resulted in reduced coastal ecosystem services. This has a negative impact in the form of the capacity of the biosphere to absorb greenhouse gases, especially carbon dioxide $\left(\mathrm{CO}_{2}\right)$ [19].

The concept of mitigating the effects of greenhouse gases (GHG) and climate change can be done by reducing GHG emissions and maintaining ecosystem services to absorb carbon. This concept can be applied through the implementation of various land and coastal vegetation management programs, carrying out effective land-use control and vegetation conservation and sustainable emission control. Efforts to maintain coastal ecosystem services to absorb carbon can be carried out by conserving and rehabilitating ecosystems [19]. Conservation of mangrove forests can reduce global carbon emissions. Despite the benefits of climate change mitigation and adaptation, mangrove forests show deforestation or degradation at an alarming rate, although restoration efforts can offset these losses. The impact of deforestation on carbon stocks is relatively intuitive and results in a significant reduction in carbon stocks. It remains unclear how degradation from cutting down mangroves affects carbon stocks or how effective restoration efforts restoring carbon stocks. Besides, the total carbon stock of native mangrove forests can vary widely spatially [22].

The Government of the Republic of Indonesia, through Presidential Regulation Number 61 of 2011 [23] concerning the National Action Plan for Greenhouse Gases (RAN GRK) has committed that by 2020, Indonesia will reduce emissions by $26 \%$ (up to $29 \%$ by 2030) on its own and up to $41 \%$ with external support. The emission reduction target is still focused on the land base sector, while the coastal and marine sectors have not received serious attention. Data and information regarding the carbon stocks and removals of coastal vegetation ecosystems can be used to calculate the target for reducing greenhouse gas (GHG) emissions [19]. Carbon storage by coastal habitat vegetation (mangroves, salt marshes, and seagrasses) is recognized as an essential ecosystem service at the global level [24].

The Ministry of National Development Planning/ Bappenas is preparing a draft of Presidential Regulation (Perpres) on Low Carbon Development Planning (PPRK). According to the release at the end of 2017, environmentally friendly materials in every aspect of development, from planning, implementation, to evaluation will be included in this Perpres [25]. Ecosystem conservation and rehabilitation programs are essential points in national and regional development planning for 2020-2030, especially in sustainable coastal area management. Maintaining the sustainability of coastal ecosystems is a crucial component in conservation and rehabilitation efforts. These efforts include maintaining extensive areas of vegetation and ecosystem services. Thus, coastal vegetation can maintain avoided emissions and reduce the potential for $\mathrm{CO}_{2}$ emissions (released) from land-use conversion [19]. It is said that mangrove forests are good for biomass production, carbon sequestration, and storage if not converted into some other land use. Therefore, mangrove forests must be managed and protected to maximize their role in the global carbon cycle, in the conservation of coastal biodiversity [26].

Bombana Regency is one of the regencies in Southeast Sulawesi with the capital city of Rumbia. Kabaena Island is one of Bombana Regency areas with quite a lot of industrial activities such as mining, plantations, agriculture, and transportation, which produce a lot of carbon emissions in the air. Kabaena Island, especially West Kabaena Subdistrict, is part of Bombana Regency with a mangrove land cover 
area of around 366.49 ha, which has an essential function in absorbing carbon emissions [27]. Mangrove forests are generally found on the Kabaena coast and live and thrive in locations with a tidal influence (tides) that seeps into the river flows along the coast.

Kabaena Island is one of the areas that are rich in minerals. There is a lot of land demand for industrial areas such as mining, plantations, agriculture, transportation routes, and others that contribute a lot of carbon emissions in the air. Kabaena Island, especially Kabaena Barat Subdistrict, as a mangrove forest provider located in Bombana Regency, is significant to find out how much carbon storage occurs from these industrial activities. Based on the above background, it is necessary to research the potential of blue carbon stocks and carbon dioxide uptake in mangrove forests to support low carbon emission development in Kabaena Barat
Subdistrict, Bombana Regency. Accurate and locationspecific calculation of carbon stocks and greenhouse gas emissions in mangrove forests is very important to determine the spatial range of coastal blue carbon. Accurate quantification is also required to estimate future carbon cycles due to habitat loss, degradation, preservation, or restoration [28]. This study aims to determine carbon storage and $\mathrm{CO}_{2}$ absorption in mangrove forests in Kabaena Barat Subdistrict, Bombana Regency.

\section{MATERIAL AND METHOD}

This research was conducted in the mangrove forest area of Kabaena Barat Subdistrict, Bombana Regency. For more details, the research location can be seen on the map (Fig. 1) below.

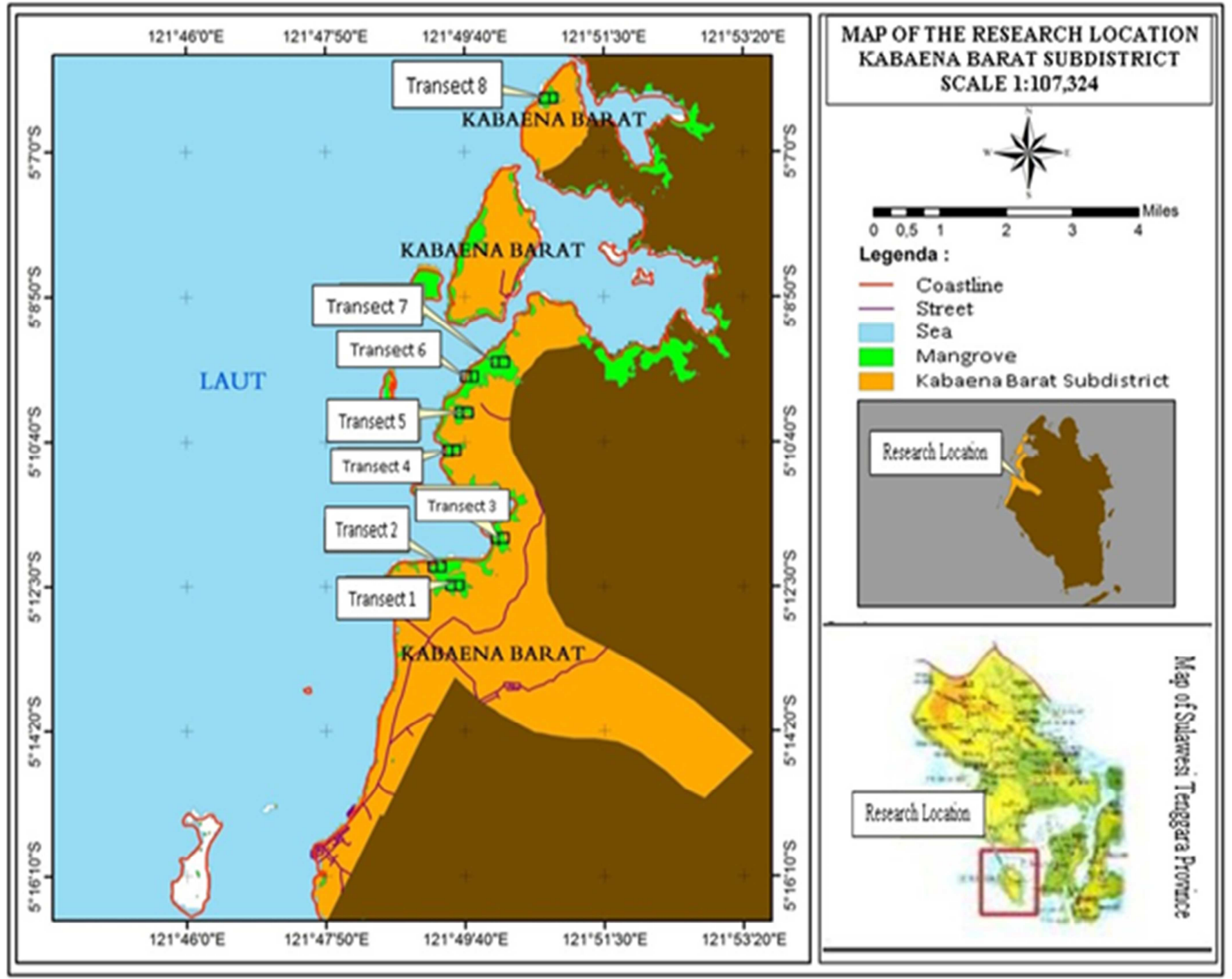

Fig. 1 Map of the research location

This research was conducted from June to July 2017. The data is sourced from direct measurements in the field, namely, aboveground carbon. The stand variable's measurement was carried out without damaging the trees or non-destructive sampling, only covering the tree vegetation carbon. It is the largest proportion of carbon storage on land to reduce destructive action if it does not destroy litter, underground vegetation, and soil. Collecting data in this study used survey methods and transect methods. The survey method is used to obtain field data using observation and measurement, such as identifying mangrove species, circumference, tree trunk diameter at breast height (dbh), 
biomass, carbon storage, and $\mathrm{CO}_{2}$ absorption from each type of mangrove vegetation.

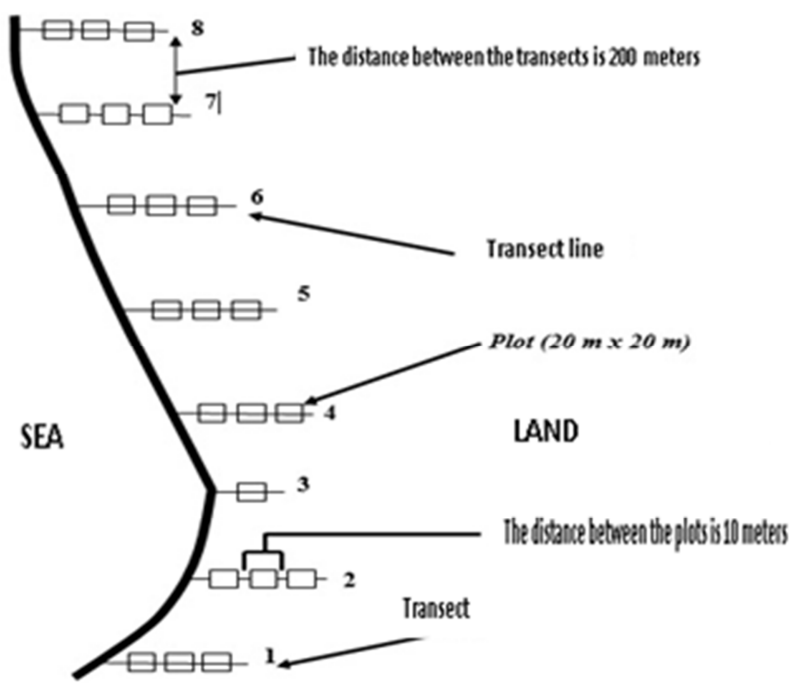

Furthermore, the checkered line method (transect), namely the initial path is determined deliberately, then the subsequent paths and plots are taken systematically. Based on the mangrove land cover in Kabaena Barat Subdistrict, Kabaena Island, the research sample unit's total area with a sampling intensity of $10 \%$ of the existing population area. This is due to the dense vegetation and many types of trees. The minimum area is determined based on increasing the plot area, which does not cause an increase in the number of species greater than $10 \%$, and rectangular sample units are more effective than square squares [29]. Sampling was based on the location zone of mangrove forest vegetation density in each sample unit area. Each location consisted of 3 observation plots in one transect with a size of each $20 \mathrm{~m} \mathrm{x}$ $20 \mathrm{~m}=400 \mathrm{~m}^{2}$ in each transect. Then note each tree's name and measure the stem diameter at breast height $(\mathrm{dbh}=1.3 \mathrm{~m}$ from ground level). The schematic of the placement of station transects and plots is shown in (Fig. 2). While measuring and determining the dbh can be done as in (Fig. $3)$.

Fig. 2 Schematic of transect placement and plots in each station in the research location

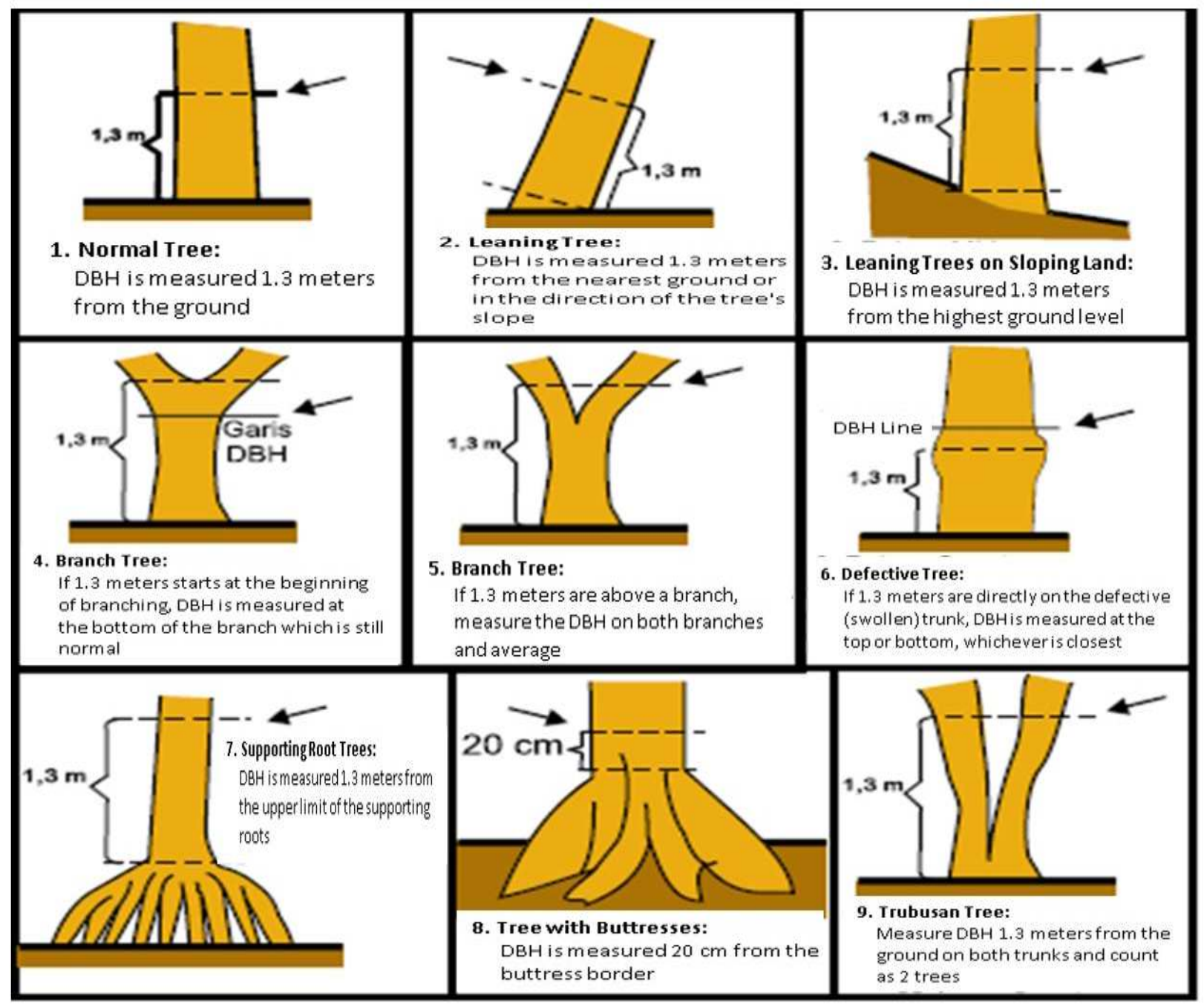

Fig. 3 Measurement and determination of DBH tree trunks of various forms [30] 
Furthermore, the data obtained from direct observations and measurements in the field are then analyzed using several equations.

\section{A. Total Dry Weight in Trees (Biomass)}

In calculating tree biomass, an allometric equation is used for mangrove trees [27], as shown in Table 1.

TABLE I

Calculation Of Mangrove Tree Biomass Using Allometric EQUATIONS

\begin{tabular}{|c|c|c|}
\hline $\begin{array}{l}\text { Mangrove } \\
\text { Type Name }\end{array}$ & $\begin{array}{l}\text { Allometric } \\
\text { Equations }\end{array}$ & Source \\
\hline $\begin{array}{l}\text { Aegiceras } \\
\text { floridum }\end{array}$ & $B=0.251 \rho(D)^{2,46}$ & Komiyama et al., 2005 [49] \\
\hline Avicennia alba & $\mathrm{W}=0.2901(\mathrm{D})^{2,2605}$ & $\begin{array}{l}\text { Siregar and Dharmawan, } \\
2009[50]\end{array}$ \\
\hline $\begin{array}{l}\text { Avecenia } \\
\text { lanata }\end{array}$ & $\mathrm{W}=0.2901(\mathrm{D})^{2,605}$ & $\begin{array}{l}\text { Siregar and Dharmawan, } \\
2009[50]\end{array}$ \\
\hline $\begin{array}{l}\text { Avicennia } \\
\text { marina }\end{array}$ & $\mathrm{B}=0.1848(\mathrm{D})^{2,3624}$ & $\begin{array}{l}\text { Dharmawan and Siregar, } \\
2008[51]\end{array}$ \\
\hline Avicennia sp & $\mathrm{B}=0.251 \rho(\mathrm{D})^{2,46}$ & Komiyama et al., 2005 [49] \\
\hline $\begin{array}{l}\text { Brugueira } \\
\text { cylindrical }\end{array}$ & $\mathrm{B}=0.251 \rho(\mathrm{D})^{2,46}$ & Komiyama et al., 2005 [49] \\
\hline $\begin{array}{l}\text { Bruguiera } \\
\text { gymnorhiza }\end{array}$ & $\mathrm{B}=0.0754(\mathrm{D})^{2,505}$ & $\begin{array}{l}\text { Kauffman and Donato., } \\
2012 \text { [52] }\end{array}$ \\
\hline Ceriops tegal & $\mathrm{B}=0.251(\mathrm{D})^{2,46}$ & Komiyama et al., 2005 [49] \\
\hline $\begin{array}{l}\text { Lumnitzera } \\
\text { racemosa }\end{array}$ & $\mathrm{B}=0.251(\mathrm{D})^{2,46}$ & Komiyama et al., 2005 [49] \\
\hline $\begin{array}{l}\text { Rhizophora } \\
\text { apiculata }\end{array}$ & $\mathrm{B}=0.043(\mathrm{D})^{2,63}$ & Amira, 2008 [53] \\
\hline $\begin{array}{l}\text { Rhizophora } \\
\text { mucronata }\end{array}$ & $\mathrm{B}=0.128(\mathrm{D})^{2,60}$ & Fromard et al., 1998 [54] \\
\hline $\begin{array}{l}\text { Rhizophora } \\
\text { stylosa }\end{array}$ & $\mathrm{B}=0.128(\mathrm{D})^{2,60}$ & Fromard et al., 1998 [54] \\
\hline $\begin{array}{l}\text { Scyphiphora } \\
\text { hydrophyllacea }\end{array}$ & $\mathrm{B}=0.251(\mathrm{D})^{2,46}$ & Komiyama et al., 2005 [49] \\
\hline $\begin{array}{l}\text { Sonneratia } \\
\text { alba }\end{array}$ & $\mathrm{B}=0.3841(\mathrm{D})^{2,101}$ & $\begin{array}{l}\text { Kauffman and Donato., } \\
2012[52]\end{array}$ \\
\hline $\begin{array}{l}\text { Xylocarpus } \\
\text { granatum }\end{array}$ & $\mathrm{B}=0.1832(\mathrm{D})^{2,21}$ & Tarlan, 2008 [55] \\
\hline
\end{tabular}

\section{B. Biomass Per Unit Area (ton ha-1)}

Biomass per unit area can be found using the following formula 1 [31]:

$$
\text { Biomass per unit area }=\frac{\text { Total Biomass }}{\text { Large area }}
$$

\section{Estimated Carbon Stored}

The estimation of the amount of carbon stored per component can be calculated by multiplying the biomass's total weight by the carbon concentration. The dry weight of the carbon storage component in a certain area is then converted to its carbon value by the following formula 2 [31]:

$$
\text { Carbon stock }=\text { Biomass per unit } x 0.46
$$

\section{CO2 Absorption Calculation}

The amount of $\mathrm{CO}_{2}$ absorption by mangroves can be determined using the following formula 3 [31]:

$$
\mathrm{CO}_{2} \text { absorption }=\frac{\mathrm{M}_{r} \mathrm{CO}_{2}}{A_{r} \mathrm{C}} \times \text { Concentration } \mathrm{C}
$$

Information:

$\mathrm{MrCO}_{2}=$ The molecular weight of the compound (44)

$\mathrm{Ar} \mathrm{C}=$ Relative molecular weight of atoms C (12)

\section{RESULTS AND DISCUSSION}

Astronomically, Kabaena Barat Subdistrict is located between $5^{\circ} 07^{\prime} 10^{\prime \prime}-5^{\circ} 16^{\prime} 47.4^{\prime \prime}$ South Latitude and between $121^{\circ} 45^{\prime} 46.7^{\prime \prime}-121^{\circ} 53^{\prime} 30.4^{\prime \prime}$ East Longitude. The area of Kabaena Barat Subdistrict is $39.43 \mathrm{~km}^{2}$. Administratively, Kabaena Barat Subdistrict Kabaena Island consists of 5 villages, 18 hamlets. Rahantari Village has the largest 20.74 $\mathrm{km}^{2}$, while Sikeli Village has the smallest area, which is only $1.22 \mathrm{~km}^{2}$. The capital of Kabaena Barat Subdistrict Kabaena Island is in Baliara Village. The distance from the subdistrict capital to the regency is $89 \mathrm{~km}$ from the sub-district capital's length with a sea level of $25 \mathrm{~m}$. Kabaena Island, especially Kabaena Barat Subdistrict, is part of Bombana Regency with a mangrove land cover area of around 366.49 ha [27].

The mangrove forest in the research location is divided into 8 transects with each transect distance of 200 meters, totaling 22 plots. Several forest locations have been damaged due to the clearing of forest land to be used as ponds. Besides, some of the damage that has occurred was also caused by logging activities by the surrounding community for use as firewood. The mangrove ecosystem at the research location is also passed by a river that cuts in the middle of the forest area. At the end of this river, the community uses the location as a sand mining area. Some mangrove forest areas still have a relatively very high density, making it quite challenging to walk through these areas.

The mangrove forest in Kabaena Barat Subdistrict is unspoiled. Based on the results of the research conducted, 10 types of mangrove species were found on 8 observation transects including A. alba, A. marina, A. lanata, Avicennia sp., B. cylindrica, B. gymnorhiza, $R$. apiculata, $R$. mucronata, $S$. alba, and $X$. granatum. Mangrove ecosystems can thrive in muddy coastal areas with calm water and protected from big waves' influence. The growth of mangrove vegetation is influenced by environmental factors such as salinity. Salinity is an environmental factor that greatly determines mangrove forests' development, namely around $30 \%$ - $35 \%$, especially for the growth rate, durability, and zoning of mangrove species [32]. The water's $\mathrm{pH}$ value also affects mangrove growth, which ranges from 8.0 - 9.0 [33]. A high $\mathrm{pH}$ value further supports the decomposing organisms to decompose the organic matter that falls in the mangrove area so that mangrove soil with a high $\mathrm{pH}$ value has the same carbon as the soil profile it has.

The salinity level in Kabaena has a range between $31 \%$ $34 \%$ with an average value of $32.75 \%$ [33]. The salinity value found in Kabaena can be said to be still on a standard scale. The salinity value of waters that can support organisms' lives ranges from $33 \%$ - 34\% [34]. While the degree of acidity $(\mathrm{pH})$ from the results of the Kabaena Island study ranged from 8.16 to 8.39 with an average value of 8.24. The change in the value of the degree of acidity $(\mathrm{pH})$ in the waters depends on the photosynthetic process in the waters.

The inundation class into 4 classes, namely 10-30\%o salinity, the soil is inundated 1-2 times a day or at least 20 days per month, Avicennia or Sonneratia species on new and soft soils or Rhizophora on harder soils that form outer zoning. Salinity $10-30 \%$, the soil is flooded 9-10 days per month. B. gymnorhiza grows well and the stands form 
central zoning. While the salinity is $10-30 \%$, the soil is inundated 9 days or at least 4 times per month. Xylocarpus species thrive here and form the third zoning. Then at 10-30\% salinity, the soil is inundated for only a few days per month. The Bruguiera species are well developed and form deep zoning [35].

The mangrove tree species on transect 1 with $R$. mucronata and $A$. lanata are tree species inhabiting plot 1 with 6 trees of vegetation each. Meanwhile, the least species found were $R$. apiculata, namely 2 trees. $R$. apiculata and $R$. mucronata were also found in plot 2 with vegetation magnitude of 9 and 8 trees and the lowest species found were $X$. granatum as many as 3 trees. $R$. apiculata was also found in plot 3 with the highest amount of vegetation, namely 8 trees and the lowest vegetation in this plot was $B$. cylindrica which only reached 1 tree. Substrate characteristics are a limiting factor on the growth of mangrove ecosystems, seen in transect 1 species Rhizophora $s p$. more dominate each plot in the transect because it has good root adaptation to the substrate conditions in transect 1 , Kabaena Barat Subdistrict, which is muddy. The mangrove species Rhizophora $s p$. is the dominant vegetation in areas with a deep mud substrate [36].

Transect 2 is the transect with the best ecosystem conditions and has the greatest diversity of species compared to other transects. Plot 4 is inhabited by quite a lot of mangrove species including $R$. mucronata with the highest number of species, namely 7 trees and the lowest vegetation is A. alba and B. gymnorhyza with 1 tree each. Meanwhile, in plot $5, R$. mucronata has the most vegetation with 8 trees and $B$. cylindrica is the lowest species in this plot with 1 tree. Plot 6, which is directly facing the sea, has the highest number of vegetation diversity compared to other plots inhabited by the most species, namely $R$. mucronata with 8 trees, while A. alba is the lowest species with 1 tree. Having a good ecosystem and vegetation density means that plot 6 has the highest level of diversity than other plots. In transect 2 , the $R$. mucronata species dominate the research station, as it is known that the $R$. mucronata species can grow and adapt well to deep or thick and muddy substrate conditions because it has the shape of supporting roots such as anchors that stick into the soil or mud so that it can support the tree trunks well [37].

Transect 3 has a damaged ecosystem, so there are only a few trees left. $R$. mucronata was the highest species with 5 trees and A. alba was the lowest species in plot 7, which only reached 1 tree species. This is due to many land clearing and mangrove forests in direct contact with community settlements, which causes a lack of tree species on this transect and limits the taking of the research plot so that there is only one plot in transect 3 . The same is the case with the previous transects, namely transects 1 and 2 , for transect 3 was then found again by the mangrove species $R$. mucronata dominating the research station because transect 3 is still in a regional component with deep mud substrate properties [38].

Transect 4 is a transect that is passed by a river. In plot 8 , there are $R$. mucronata species that dominate the location with 15 trees. Besides, there is also A. alba, which is the lowest species in this plot, reaching 6 trees. In plot 9, there are $S$. alba species that dominate with the number of trees, namely 7 trees and the lowest species are A. alba and $R$. mucronata with 2 trees each. $R$. apiculata species were again found in plot 10 with the highest number of species reaching 9 trees and A. alba and A. marina species with the lowest number of each of 2 trees. Transect 4 has the same substrate characteristics as the previous transect, namely muddy and high salinity. These environmental factors are good soil conditions for the distribution of the mangrove species $R$. mucronata.

On transect 5 in plot 11 again found $X$. granatum species with the highest number of species reaching 14 trees, followed by $R$. mucronata with the lowest species of 1 tree. In plot 12 , there are only 3 types of mangrove trees, the highest number of which is occupied by $B$. gimnorhiza with 13 trees and the lowest species is $X$. granatum with 9 trees. In plot 13 , there is A. lanata species which has the highest tree species with 12 trees. Meanwhile, the lowest species was found in $R$. mucronata with 3 trees. Types of Bruguiera $s p$. is a type of mangrove tree belonging to the same family as Rhizophora sp. both have relatively the same growth rate, which is the habitat of Bruguiera sp. after that the habitat of Rhizophora $s p$. Usually, Bruguiera $s p$. grows in relatively hard soil habitats with relatively lower salinity when compared to the habitat of Rhizophora sp. The salt content of the habitat where Bruguiera sp. is 0.5 times the salt content where Rhizophora sp. [32].

Furthermore, on transect 6 in plot 14, 3 mangrove species were found, with the highest vegetation type being $R$. apiculata with 9 trees and the lowest species being $R$. mucronata, 7 trees. In plot 15, only 2 types of mangroves were found, this is because they are influenced by salinity, tolerance to waves and wind, tolerance to mud, and frequency of waterlogging [39]. Whereas in plot 16, there are $R$. apiculata species that dominate with 8 trees of vegetation and the lowest species is B. gymnorhiza with 5 trees.

Transect 7 is the location most in contact with the open sea which has wave resistant vegetation so that in plot 17 there are 9 types of $B$. gymnorhiza which dominate the highest, while the lowest type is $X$. granatum with 6 trees. In plot 18 there are 3 species with $R$. mucronata as the most species in the plot, namely 20 trees and the lowest species is B. gymnorhiza with 2 trees. Meanwhile, in plot $19, R$. mucronata was found to dominate the research plot with many vegetation, namely 18 trees and the lowest species was in the B. gymnorhiza species with 3 trees of vegetation.

On transect 8, many Avicennia species were found, including in plot 20 there were Avicennia sp. and on plot 21 there are types A. alba, A. lanata, A. marina. Meanwhile, the highest species in plot 20 was $B$. gymnorhiza with 10 trees and the lowest was $X$. granatum with 6 trees. In plot 21 , there are many types of vegetation with the most types, namely A. alba with 9 trees and the lowest is Avicennia sp. and $X$. granatum with 1 tree each. Whereas in plot 22 there were only 3 types of mangrove trees, namely $R$. apiculata, $R$. mucronata, and $S$. alba with the highest species being $S$. alba with 12 trees and the lowest was $R$. apiculata with 5 trees.

The transects 6,7 , and 8 are transects dominated by mangroves of the $R$. mucronata species. $R$. mucronata species have a wide distribution in terms of the classification 
system, this species belongs to the genus Rhizophora $s p$. which has a wide distribution pattern for mangrove forests and has good adaptability to muddy and sandy substrate conditions. In Indonesia it is very good for mangrove stands of Rhizophora sp. and Avicennia sp. [37].

Forests can absorb carbon because forests are a collection of trees with biological activities such as photosynthesis and respiration. In the process of photosynthesis, trees (plants) absorb $\mathrm{CO}_{2}$ and $\mathrm{H}_{2} \mathrm{O}$, assisted by sunlight, are converted into glucose which is a source of energy (previously converted through the process of respiration) of the plant and produces $\mathrm{H}_{2} \mathrm{O}$ and $\mathrm{O}_{2}$, which are elements needed by organisms to carry on life (breathe). It is necessary to realize that humans need forests to absorb excess carbon in the atmosphere. The research results in Kabaena Barat Subdistrict's mangrove forests show that the amount of biomass, carbon storage, and $\mathrm{CO}_{2}$ uptake at the tree level shows a striking difference between each plot and transect; it can be seen in Table 2 and Table 3.

TABLE II

Amount of Biomass, Carbon Deposits And Co2 Uptake In EACH Plot In MANGrove Forest, Kabaena Barat SubdistRict, Bombana RegenCy

\begin{tabular}{|c|c|c|c|c|c|c|c|c|c|}
\hline No. & Area & Plots/transects & $\begin{array}{c}\text { Biomass } \\
(\mathrm{kg})\end{array}$ & $\begin{array}{c}\text { Carbon } \\
(\mathbf{k g})\end{array}$ & $\begin{array}{c}\text { Biomass } \\
(\mathrm{kg} / \mathrm{ha})\end{array}$ & $\begin{array}{l}\text { Carbon } \\
(\mathrm{kg} / \mathrm{ha})\end{array}$ & $\begin{array}{c}\text { Biomass } \\
\text { (ton ha } \\
\text { 1) }\end{array}$ & $\begin{array}{c}\text { Carbon } \\
\left(\text { ton ha }^{-1}\right)\end{array}$ & $\begin{array}{c}\mathrm{CO}_{2} \\
\text { Absorption } \\
{\left.\text { (ton } \mathrm{ha}^{-1}\right)}^{-1}\end{array}$ \\
\hline 1 & Kabaena Barat Subdistict & Plot $1 /$ transect 1 & $9,216.93$ & $4,239.79$ & $230,423.37$ & $105,994.75$ & 230.42 & 105.99 & 388.64 \\
\hline 2 & Kabaena Barat Subdistict & Plot 2/transect 1 & $6,932.90$ & $3,189.13$ & $173,322.65$ & $79,728.42$ & 173.32 & 79.72 & 292.33 \\
\hline 3 & Kabaena Barat Subdistict & Plot 3/transect 1 & $15,842.38$ & $7,287.49$ & $375,703.47$ & $172,823.59$ & 375.70 & 172.82 & 668.02 \\
\hline 4 & Kabaena Barat Subdistict & Plot $4 /$ transect 2 & $11,578.16$ & $5,325.95$ & $289,454.01$ & $133,148.84$ & 289.45 & 133.14 & 488.21 \\
\hline 5 & Kabaena Barat Subdistict & Plot 5/transect 2 & $14,859.12$ & $6,835.19$ & $371,478.24$ & $170,879.99$ & 371.47 & 170.88 & 626.55 \\
\hline 6 & Kabaena Barat Subdistict & Plot 6/transect 2 & $11,126.19$ & $5,118.04$ & $278,154.88$ & $127,951.24$ & 278.15 & 127.95 & 469.15 \\
\hline 7 & Kabaena Barat Subdistict & Plot $7 /$ transect 3 & $6,039.72$ & $2,778.27$ & $150,993.23$ & $69,456.88$ & 150.99 & 69.45 & 254.67 \\
\hline 8 & Kabaena Barat Subdistict & Plot 8/transect 4 & $15,353.17$ & $7,062.46$ & $383,829.36$ & $176,561.50$ & 383.82 & 176.56 & 647.39 \\
\hline 9 & Kabaena Barat Subdistict & Plot 9/transect 4 & $8,483.26$ & $3,902.29$ & $212,081.50$ & $97,557.49$ & 212.08 & 97.55 & 357.71 \\
\hline 10 & Kabaena Barat Subdistict & Plot 10/transect 4 & $9,493.77$ & $4,367.13$ & $237,344.30$ & $109,178.38$ & 237.34 & 109.17 & 400.32 \\
\hline 11 & Kabaena Barat Subdistict & Plot 11/transect 5 & $10,007.24$ & $4,603.33$ & $250,181.17$ & $115,083.33$ & 250.18 & 115.08 & 421.97 \\
\hline 12 & Kabaena Barat Subdistict & Plot $12 /$ transect 5 & $12,120.26$ & $5,575.32$ & $303,006.60$ & $139,383.03$ & 303.00 & 139.38 & 511.07 \\
\hline 13 & Kabaena Barat Subdistict & Plot 13/transect 5 & $29,185.51$ & $13,425.33$ & $729,637.85$ & $335,633.41$ & 729.63 & 335.63 & $1,230.65$ \\
\hline 14 & Kabaena Barat Subdistict & Plot 14/transect 6 & $6,192.27$ & $2,848.44$ & $154,806.87$ & $71,211.16$ & 154.80 & 71.21 & 261.10 \\
\hline 15 & Kabaena Barat Subdistict & Plot $15 /$ transect 6 & $7,454.81$ & $3,429.21$ & $186,370.33$ & $85,730.35$ & 186.37 & 85.73 & 314.34 \\
\hline 16 & Kabaena Barat Subdistict & Plot 16/transect 6 & $12,267.29$ & $5,642.95$ & $306,682.39$ & $141,073.90$ & 306.68 & 141.07 & 517.27 \\
\hline 17 & Kabaena Barat Subdistict & Plot 17/transect 7 & $13,107.45$ & $6,029.42$ & $327,686.35$ & $150,735.72$ & 327.68 & 150.73 & 552.69 \\
\hline 18 & Kabaena Barat Subdistict & Plot 18/transect 7 & $16,007.44$ & $7,363.42$ & $400,186.10$ & $184,085.60$ & 400.18 & 184.08 & 674.98 \\
\hline 19 & Kabaena Barat Subdistict & Plot 19/transect 7 & $11,425.61$ & $5,255.78$ & $285,640.39$ & $131,394.58$ & 285.64 & 131.39 & 481.78 \\
\hline 20 & Kabaena Barat Subdistict & Plot $20 /$ transect 8 & $7,844.71$ & $3,608.56$ & $196,117.77$ & $90,214.17$ & 196.11 & 90.21 & 330.78 \\
\hline 21 & Kabaena Barat Subdistict & Plot 21/transect 8 & $21,094.57$ & $9,703.50$ & $527,364.36$ & $242,587.60$ & 527.36 & 242.58 & 889.48 \\
\hline 22 & Kabaena Barat Subdistict & Plot $22 /$ transect 8 & $10,966.16$ & $5,044.43$ & $274,154.24$ & $126,110.95$ & 274.15 & 126.11 & 462.40 \\
\hline
\end{tabular}

Source: Primary data after processing, 2017

TABLE III

Amount Of Biomass, CARbon Deposits AND CO2 UptaKe At EACH TRANSECT IN KABAENA BARAT SUBDISTRICT, BOMBANA REGENCY

\begin{tabular}{|c|c|c|c|}
\hline $\begin{array}{c}\text { Trans } \\
\text { ect }\end{array}$ & $\begin{array}{c}\text { Biomass } \\
\left(\text { ton ha }^{-1}\right)\end{array}$ & $\begin{array}{c}\text { Carbon Deposits } \\
\left(\text { ton } \mathrm{ha}^{-1}\right)\end{array}$ & $\begin{array}{c}\mathrm{CO}_{2} \text { Absorption } \\
\left(\text { ton } \mathrm{ha}^{-1}\right)\end{array}$ \\
\hline 1 & 799.80 & 367.91 & $1,349.00$ \\
\hline 2 & 939.08 & 431.98 & $1,583.92$ \\
\hline 3 & 150.99 & 69.45 & 254.67 \\
\hline 4 & 833.25 & 383.29 & $1,405.42$ \\
\hline 5 & $1,282.82$ & 590.09 & $2,163.69$ \\
\hline 6 & 647.85 & 298.01 & $1,092.72$ \\
\hline 7 & $1,013.51$ & 466.21 & $1,709.45$ \\
\hline 8 & 997.63 & 458.91 & $1,682.68$ \\
\hline Total & $6,664.93$ & $3,065.85$ & $11,241.55$ \\
\hline
\end{tabular}

Source: Primary data after processing, 2017

In the process of photosynthesis, plants absorb $\mathrm{CO}_{2}$ from the air with the help of other sunlight. The photosynthetic reaction process occurs through the following equation (4):

$$
6 \mathrm{CO}_{2}+6 \mathrm{H}_{2} \mathrm{O} \rightarrow \mathrm{C}_{6} \mathrm{H}_{12} \mathrm{O}_{6}+6 \mathrm{O}_{2}
$$

Carbon in plants is bound in organic matter and distributed in cellulose (40\%), other polysaccharides $(26 \%)$, and lignin $(30 \%)$. Meanwhile, the lignin distribution in the cell walls and lignin content in tree parts is not the same [40]. This means that each part of the tree has different lignin content so that the percentage of carbon specifically bound to the lignin for each part of the tree will also be different. Therefore, the proportion of the biomass's carbon content for each component of the tree will also be different.

The mangrove forest is one of the wetland ecosystems with high soil carbon stocks after the peatland ecosystem. Stored carbon will increase from the beginning of the plant growth phase until it reaches a stable value with increasing stand age. The stability of carbon stock value occurs when the amount of carbon absorbed is equal to the amount of carbon emitted due to plant respiration. The level of vegetation density also influences the ability of carbon absorption in an area. Parameters affecting the variability of mangrove carbon storage have been assessed at different 
spatial scales. Site-specific variations have been associated with differences in vegetation structure [41]; [42], sediment texture [43], and elevation gradients and tidal patterns [12]. At the regional level, variability in mangrove carbon storage has been linked to trends in net primary productivity as well as coastal geomorphology of biogeography [44]; [11], whereas at the global level, it is explained by Holocene trends in sea level [45].

The absorption of carbon from the photosynthesis process converts inorganic carbon $\left(\mathrm{CO}_{2}\right)$ into organic carbon in vegetation. In some ecosystems, this material decays and releases carbon back into the atmosphere as $\mathrm{CO}_{2}$. However, mangrove forests contain large amounts of organic matter that does not decompose. Therefore, mangrove forests function more as carbon sinks when compared to other natural forests as carbon sources. In obtaining the maximum carbon absorption potential, it is necessary to emphasize the activities of increasing aboveground biomass instead of carbon in the soil. Carbon stocks in aboveground biomass and biomass distribution vary according to mangrove forest age and mangrove tree density, which depend on depletion activity [46].

Table 3 shows that the amount of biomass and carbon storage in each transect is different because several factors cause each mangrove found in the area. One aspect is the number of each type being different at the study location and differences in stem diameter size. Mangrove biomass content will increase with the age of the plant. This is because the tree's diameter grows through continuous cell division and gets slower at a certain age.

The distribution of biomass in each part of the tree describes the amount of distribution of photosynthetic products stored by plants. Although photosynthetic activity occurs in leaves, it turns out that the largest distribution of photosynthetic products is used for stem growth. Stems that have a large diameter will have the ability to absorb even greater $\mathrm{CO}_{2}$ because the results of tree photosynthesis are generally stored in the trunk. It makes the organic materials contained in the trunk are more extensive than other parts which have wood components in the form of natural polymers by $97 \%$ - $99 \%$ [47]. Stems are the most considerable contribution to the total dry weight aboveground biomass, and leaves are the lowest. The distribution of biomass varies according to the mangrove forest's age, with a greater allocation of branches and roots as the tree develops to maintain stability in a muddy substrate [46].

The biomass potential of good mangrove ecosystems in Southeast Asia is ranging from 250-275 tons $\mathrm{ha}^{-1}$ or carbon stocks ranging from 115-126.5 tons $\mathrm{C} /$ ha. Meanwhile, the lowest biomass potential is less than 7.9 tons $\mathrm{ha}^{-1,}$ or carbon stock is around 3.63 tons ha ${ }^{-1}$. Based on this, it can be said that the research area can be categorized as very high carbon absorption [38].

Based on the results of research from 22 plots divided into 8 transects, it was found that the value of each mangrove species contained different biomass and stored carbon. This was seen from the use of different calculation coefficient values for each species [1]. In the research location, the highest total biomass content of each transect starts from transect 5 with the total biomass of 1,282.82 tons $\mathrm{ha}^{-1}$ and carbon storage of 590.09 tons $\mathrm{ha}^{-1}$ and $\mathrm{CO}_{2}$ absorption of
2,163.69 $\mathrm{C} \mathrm{ha}^{-1}$, then followed by transect 7 with a total biomass of 1,013.51 tons ha $^{-1}$ and carbon storage of 466.21 tons $\mathrm{ha}^{-1}$ and $\mathrm{CO}_{2}$ uptake of $1,709.45 \mathrm{C} \mathrm{ha}^{-1}$. There is transect 8 with a total biomass of 997.63 tons of $\mathrm{ha}^{-1}$ and carbon storage of 458.91 tons $\mathrm{ha}^{-1}$ and $\mathrm{CO}_{2}$ absorption of $1,682.68 \mathrm{C} \mathrm{ha}^{-1}$ in the next position, followed by transect 2 with the amount of biomass of 939.08 tons $\mathrm{ha}^{-1}$ and carbon storage of 431.98 tons ha ${ }^{-1}$ and $\mathrm{CO}_{2}$ absorption as much as 1,583.92 $\mathrm{C} \mathrm{ha}^{-1}$.

Furthermore, there is transect 4 with the total biomass of 833.25 tons $^{-1} \mathrm{a}^{-1}$ and carbon storage of 383.29 tons $^{-1} \mathrm{a}^{-1}$ and $\mathrm{CO}_{2}$ absorption of $1,405.42 \mathrm{C} \mathrm{ha}^{-1}$ and then transect 1 with the amount of biomass of 799.80 tons $\mathrm{ha}^{-1}$ and carbon storage of 367.91 tons $\mathrm{ha}^{-1}$ and $\mathrm{CO}_{2}$ absorption of $1,349.00$ $\mathrm{C} \mathrm{ha}^{-1}$. After that, there is transect 6 with a total biomass of 647.85 tons $\mathrm{ha}^{-1}$ and carbon storage of 298.01 tons $^{-1}$ and $\mathrm{CO}_{2}$ absorption of $1,092.72 \mathrm{C} \mathrm{ha}^{-1}$, and the last is transect 3 with a total biomass of 150,99 tons $\mathrm{ha}^{-1}$ and carbon storage of 69.45 tons ha ${ }^{-1}$ and $\mathrm{CO}_{2}$ absorption of $254.67 \mathrm{C} \mathrm{ha}^{-1}$.

The more significant biomass content and carbon storage of each transect are located on transect 5 with a total biomass of 1,282.82 tons $\mathrm{ha}^{-1}$ and a carbon storage of 590.09 tons $\mathrm{ha}^{-1}$, and $\mathrm{CO}_{2}$ absorption of $2,163.69 \mathrm{C} \mathrm{ha}^{-1}$. This happens because transect 5 still has good vegetation with a large enough tree diameter so that it produces a large amount of biomass and carbon storage when compared to transect 3 , which contains less biomass, namely 150.99 tons $^{-1}$ and savings the carbon is 69.45 tons $\mathrm{ha}^{-1}$, and $\mathrm{CO}_{2}$ absorption is 254.67 $\mathrm{C} \mathrm{ha}^{-1}$. This happens because the ecosystem has been damaged so that there are only a few trees left and the number of plot placement is small because it is close to settlements and the number of trees is very small. Another prominent factor is the clearing of land for ponds and the extraction of firewood by humans around the area itself, which results in reduced tree levels.

Carbon stock is directly proportional to its biomass content. The greater the biomass content, the greater the carbon stock of a plant. For each transects total biomass content and carbon storage, it is 6,664.93 tons ha ${ }^{-1}$ and $3,065.85$ tons $\mathrm{ha}^{-1}$. Hence, the $\mathrm{CO}_{2}$ absorption that occurs in the study area is $11,241.55 \mathrm{C} \mathrm{ha}^{-1}$. Biomass potential, carbon content, and $\mathrm{CO}_{2}$ uptake each year of planting vary; variations occur due to differences in diameter and the number of plots measured. In this study, the achievement of carbon uptake by mangrove forests in Kabaena Barat Subdistrict was still very good. Mangrove stands as forest vegetation that can absorb carbon and store it in the ecosystem stored in vegetation as a carbon sink. If mangrove forests can be maintained, they will make a significant contribution to environmental safety from the threat of global warming. Therefore, mangrove forest restoration programs must be considered a potential solution to increase ecosystem carbon storage and an essential component of coastal ecosystems, management strategies, and climate change mitigation [48].

\section{CONCLUSIONS}

Based on the results of the research conducted, 10 types of mangrove species were found from 8 observation transects including A. alba, A. marina, A. lanata, Avicennia sp., B. cylindrica, B. gymnorhiza, R. apiculata, R. mucronata, 
$S$. alba, and $X$. granatum. The total amount of biomass stored in Kabaena Barat Subdistrict's mangrove forests, Bombana Regency, is 6,664.93 tons ha- 1 with 3,065.85 tons $\mathrm{ha}^{-1}$ and $\mathrm{CO}_{2}$ absorption of $11,241.55$ tons $\mathrm{ha}^{-1}$.

\section{ACKNOWLEDGMENT}

The authors are grateful to the Regional Government of Kabaena Barat Subdistrict, Bombana Regency, which has permitted the author to conduct this research. Deepest gratitude is also extended to all field teams who helped collect data and information during this implementation.

\section{REFERENCES}

[1] E. Handoko, B. Amin, H.S. Siregar, "Analisis biomassa dan cadangan karbon pada ekosistem mangrove di Kawasan Selatan Pulau Rupat," Jurnal Online Mahasiswa Fakultas Perikanan dan Ilmu Kelautan Universitas Riau (JOM FAPERIKA UNRI), vol. 3(2), pp. 1-12, 2016

[2] M. J. Afifudin, "Analisa vegetasi hutan mangrove dan serapan $\mathrm{CO}_{2}$ di Kecamatan Tongas Kabupaten Probolinggo Jawa Timur. skripsi, Program Studi Ilmu Kelautan Fakultas Sains dan Teknologi Universitas Islam Negeri Sunan Ampel, Surabaya, 2019.

[3] M. Iswandar, I. Dewiyanti, dan V. Kurnianda, "Dugaan serapan karbon pada vegetasi mangrove di kawasan mangrove Gampong Iboih Kecamatan Sukakarya Kota Sabang," Jurnal Ilmiah Mahasiswa Kelautan dan Perikanan Unsyiah, vol. 2(4), pp. 512-518, 2017.

[4] S. Sandilyan, \& K. Kathiresan, "Density of waterbirds in relation to habitats of Pichavaram mangroves," Southern India, vol. 19(2), pp. 131-139, 2015.

[5] R. Polii, J. S. Tasirin, dan S. P. Ratag, "Analisis cadangan karbon di hutan mangrove Desa Bahoi," Jurnal Ilmiah Fakultas Pertanian Universitas Sam Ratulangi, vol. 1(2), pp. 1-6, 2019.

[6] S. Oktaviona, B. Amin, dan M. Ghalib, "Estimasi stok karbon tersimpan pada ekosistem hutan mangrove di Jorong Ujuang Labuang Kabupaten Agam Provinsi Sumatera Barat," Jurnal Online Mahasiswa Fakultas Perikanan dan Ilmu Kelautan, vol. 4(2), pp. 112, 2017.

[7] S. E. Hamilton and D. A. Friess, "Global carbon stocks and potential emissions due to mangrove deforestation from 2000 to 2012," Nature Climate Change, vol. 8(3), pp. 240-244, 2018. DOI: 10.1038/s41558018-0090-4.

[8] Y. S. Syafruddin, "Pendugaan cadangan karbon biru pada tingkat pohon di Desa Pulau Cawan dan Desa Bekawan Kecamatan Mandah Provinsi Riau," Jurnal Spasial, vol. 5(2), pp. 54-62, 2018.

[9] A. J. Wahyudi, et al., "Potensi cadangan dan serapan karbon ekosistem mangrove dan padang lamun Indonesia," Lembaga Ilmu Pengetahuan Indonesia (LIPI) Via Program Coral Reef Management and Rehabilitation-Coral Triangle Initiative (COREMAP-CTI). 2018.

[10] M. L. P. Penaranda, J. R. C. Kintz, and E. J. P. Salamanca, "Carbon stocks in mangrove forests of the Colombian Pacific," Estuarine, Coastal and Shelf Science, vol. 227, pp. 1-7, 2019. DOI: https://doi.org/10.1016/j.ecss.2019.106299.

[11] A. Rovai, R. Twilley, E. Castañeda-Moya, P. Riul, M. Cifuentes-Jara, M. Manrow-Villalobos, P. Horta, J. C. Simonassi, A. Fonseca, P. R. Pagliosa, "Global controls on carbon storage in mangrove soils," Nat. Clim. Chang, vol. 8, pp. 534-538, 2018. DOI: https://doi.org/10.1038/s41558-018-0162-5.

[12] M. A. Hayes, A. Jesse, B. Tabet, R. Reef, J. A. Keuskamp, C. E. Lovelock, "The contrasting effects of nutrient enrichment on growth, biomass allocation and decomposition of plant tissue in coastal wetlands," Plant Soil, vol. 416, pp. 193-204, 2017. DOI: https://doi.org/10.1007/s11104-017-3206-0.

[13] Badan Informasi Geospasial (BIG), "Informasi geospasial mangrove Indonesia," Pusat Pemetaan dan Informasi Tematik, Badan Informasi Geospasial Indonesia. Bogor. 2012.

[14] Kementerian Kehutanan (KLHK), "Rekalkulasi penutupan lahan Indonesia tahun 2012," Center for Forest Mapping and Inventory. Kementerian Kehutanan RI. Jakarta. 2013.

[15] M. Ilman, P. Dargusch, P. Dart, and Onrizal, "A historical analysis of the drivers of loss and degradation of Indonesia's mangroves," Land Use Policy, vol. 54, pp. 448-459, 2016.
[16] C. Giri, E. Ochieng, L. L. Tieszen, Z. Zhu, A. Singh, T. Lovelan, N Duke, Stasus and Distribution of Mangrove Forest of the World Using Actions Project, USA: Forest Ecological, 2011.

[17] M. Syukri, "Estimasi cadangan karbon vegetasi mangrove hubungannya dengan tutupan kanopi di Ampalas, Kelurahan Bebanga, Kecamatan Kalukku Kabupaten Mamuju Sulawesi Barat," skripsi, Fakultas Ilmu Kelautan dan Perikanan. Universitas Hasanuddin, Makassar, 2017.

[18] D. Murdiyarso, J. Purbopuspito, J. B. Kauffman, M. W. Warren, S. D. Sasmito, D. C. Donato, S. Manuri, H. Krisnawati, S. Taberima, \& S. Kurnianto, "The potential of Indonesian mangrove forests for global climate change mitigation," Nat. Clim. Change, vol. 5, pp. 10891092, 2015.

[19] A. J. Wahyudi, et al., (Edt), Menyerap Karbon: Layanan Ekosistem untuk Mitigasi Perubahan Iklim, Yogyakarta: Gadjah Mada University Press, 2017.

[20] R. Suwa, R. Rollon, S. Sharma, M. Yoshikai, R. N. A. Ati, G. M. G. Albano, K. O. M. A. Kusumaningtyas, T. L. Kepel, R. J. Maliao, Y. H. P. Tirol, N. S. Adi, A. C. Blanco, and K. Nadaoka, "Mangrove biomass estimation using canopy height and wood density in the South East and East Asian regions," Estuarine, Coastal and Shelf Science, 2020. DOI: https://doi.org/10.1016/j.ecss.2020.106937.

[21] B. Neumann, A. T. Vafeidis, J. Zimmermann, and R. J. Nicholls, "Future coastal population growth and exposure to sea-level rise and coastal flooding - a global assessment," PLOS ONE, vol. 10(3): e0118571. DOI: 10.1371/journal.pone.0118571, 2015.

[22] S. Sharma, R.A. MacKenzie, T. Tieng, K. Soben, N. Tulyasuwan, A Resanond, G. Blate, and C.M. Litton, "The impacts of degradation, deforestation and restoration on mangrove ecosystem carbon stocks across Cambodia," Science of the Total Environment, 2019. DOI: https://doi.org/10.1016/j.scitotenv.2019.135416.

[23] Peraturan Presiden Nomor 61 Tahun 2011 tentang Rencana Aksi Nasional Gas Rumah Kaca (RAN GRK). 2011.

[24] J. L. Johnson, J. L. Raw, and J. B. Adams, "First report on carbon storage in a warm-temperate mangrove forest in South Africa,' Estuarine, Coastal and Shelf Science, vol. 235, pp. 1-10, 2019. DOI: https://doi.org/10.1016/j.ecss.2019.106566.

[25] (2017) Katadata website. [Online]. Available: https://katadata.co.id/berita/2017/10/25/bappenas-siapkan-perpresnaan-pembangunan-rendah-karbon/

[26] J. A. A. Castillo, A. A. Apan, T. N. Maraseni, and S. G. Salmo, "Tree biomass quantity, carbon stock and canopy correlates in mangrove forest and land uses that replaced mangroves in Honda Bay, Philippines," Regional Studies in Marine Science, 2018. DOI: https://doi.org/10.1016/j.rsma.2018.08.006.

[27] Hardin, "Potensi karbon tersimpan pada ekosistem hutan mangrove Kecamatan Kabaena Barat Kabupaten Bombana," skripsi, Jurusan Ilmu Lingkungan Fakultas Kehutanan dan Ilmu Lingkungan Universitas Halu Oleo, Kendari, 2017.

[28] M. E. Hernández and D. J. Gómez, "Carbon stocks and greenhouse gas emissions $\left(\mathrm{CH}_{4}\right.$ and $\left.\mathrm{N}_{2} \mathrm{O}\right)$ in mangroves with different vegetation assemblies in the central coastal plain of Veracruz Mexico," Science of the Total Environment, 2020, DOI: https://doi.org/10.1016/j.scitotenv.2020.140276.

[29] I. Soerinegara, dan A. Indarawan, Ekologi Hutan. Bogor: Departemen Manajemen Hutan Fakultas Kehutanan IPB, 1998.

[30] K. Hairiah, dan S. Rahayu, "Pengukuran karbon tersimpan di berbagai macam penggunaan lahan," World Agroforestry CentreICRAF, SEA Regional Office, Universitas Brawijaya, Indonesia, 2007.

[31] R. Rifyunando, "Estimasi stok karbon mangrove di kawasan cagar alam Leuweu Sancang Kecamatan Cibalong Kabupaten Garut,' Universitas Pendidikan Indonesia. Bandung, 2011.

[32] R. T. Aksornkoe, Ecology and Management of Mangrove. Bangkok. Thailand: IUCN, 1993.

[33] R. Wardi, M. Ghalib, dan Mubarak, "Kondisi fisika-kimia perairan Pulau Kabaena Kabupaten Bombana Sulawesi Tenggara," Dinamika Lingkungan Indonesia, vol. 4(1), pp. 29-38, 2017.

[34] Keputusan Menteri Negara Lingkungan Hidup (Kepmen LH) Nomor 51 Tahun 2004 tentang Baku Mutu Air Laut, 2004.

[35] V. K. Chapman, Mangrove of Indo-Malesia. In: F.D. Poor and I. Dor (Eds), Hydrobiology of Mangal, Netherlands: Dr. W. Junk Publishers. 1976.

[36] E. Hilmi, A. S. Siregar, "Model pendugaan biomassa flora bakau di Kabupaten Indragiri Hilir Riau," Jurnal Biosfera, vol. 23(2), pp. 470476, 2007. 
[37] Samsumarlin, I. Rachman, \& B. Toknok, "Studi zonasi vegetasi mangrove muara di Desa Umbele Kecamatan Bumi Raya Kabupaten Morowali Sulawesi Tengah," Jurnal Warta Rimba, vol. 3(2), pp. 148-154, 2015.

[38] D. Rachmawati, Setyobudiandi, dan E. Hilmi, "Potensi estimasi karbon tersimpan pada vegetasi mangrove di wilayah pesisir Kabupaten Gombong Kabupaten Bekasi," Jurnal Omni Akuatika, vol. 13(19), pp. 85-91, 2014.

[39] T.G. Northcote, and Hartman (Ed), Worldwide Watershed Interaction and Management. Oxford, UK: Blackwell Science, 2004

[40] T. Adriono, "Pengukuran kandungan karbon (carbon stock) dengan metode karbonasi pada hutan tanaman jenis Acacia crassicarpa," tesis, Universitas Gadjah Mada. Yogyakarta, 2009.

[41] C. J. Owers, K. Rogers, and C. D. Woodroffe, "Spatial variation of above-ground carbon storage in temperate coastal wetlands," Estuar. Coast Shelf Sci., vol. 2(10), pp. 55-67, 2018. DOI: https://doi.org/10.1016/j.ecss.2018.06.002.

[42] E. S. Yando, M. Osland, M. W. Hester, "Microspatial ecotone dynamics at a shifting range limit: plant-soil variation across salt marsh-mangrove interfaces," Oecologia, 2018. DOI: https://doi.org/10.1007/s00442-018-4098-2.

[43] K. Banerjee, G. Bal, and A. Mitra, "How soil texture affects the organic carbon load in the mangrove ecosystem? a case study from Bhitarkanika, Odisha. In: Environmental Pollution," Water Science and Technology Library. Springer, Singapore, pp. 329-341, 2018. DOI: https://doi.org/10.1007/978-981-10-5792-2_27.

[44] R. R. Twilley, E. C. N. Moya, V. H. R. Monroy, and A. Rovai, "Productivity and carbon dynamics in mangrove wetlands. In: mangrove ecosystems: a global biogeographic perspective," Springer, pp. 113-162, 2017. DOI: https://doi.org/10.1007/978-3-319-622064 .5.

[45] K. Rogers, J. J. Kelleway, N. Saintilan, J. P. Megonigal, J. B. Adams, J. R. Holmquist, M. Lu, L. S. Beers, A. Zawadzki, D. Mazumder, and C. D. Woodroffe, "Wetland carbon storage controlled by millennialscale variation in relative sea-level rise," Nature, vol. 567, pp. 91-95, 2019. DOI: https://doi.org/10.1038/s41586-019-0951-7.
[46] T. V. Vinha, C. Marchand, T. V. K. Linha, D. D. Vinhc, and M Allenbachd, "Allometric models to estimate above-ground biomass and carbon stocks in Rhizophora apiculata tropical managed mangrove forests (Southern Viet Nam)," Forest Ecology and Management, vol. 434, pp. 131-141, 2018. DOI: https://doi.org/10.1016/j.foreco.2018.12.017.

[47] S. Achmadi, Diktat Kimia Kayu. Bogor: Pusat Antar Universitas. Institut Pertanian Bogor, 1990.

[48] P. V. Hieu, L. V. Dung, N. T. Tue, and K. Omori, "Will restored mangrove forests enhance sediment organic carbon and ecosystem carbon storage?," Regional Studies in Marine Science, 2017. DOI: http://dx.doi.org/10.1016/j.rsma.2017.05.003.

[49] A. Komiyama, S. Poungparn, S. Kato, "Common allometric equations for estimating the tree weight of mangroves," Journal of Tropical Ecology, vol. 21, 2005. DOI: 10.1017/S0266467405002476.

[50] C.A. Siregar dan I.W.S. Dharmawan, "Biomassa karbon pada hutan tanaman mangrove," Pusat Penelitian Hutan dan Konservasi Alam, Bogor, 2009.

[51] I.W.S. Dharmawan dan C.A. Siregar, "Karbon tanah dan penduga karbon tegakan Avicennia marina di Ciasem, Purwakarta," Jurnal Penelitian Hutan dan Konservasi Alam, 2008.

[52] J.B. Kauffman dan D.C. Donato, "Protocols the measurement, monitoring, and reporting of structure, biomass and carbon stocks in mangrove forests," Center for International Forestry Research (CIFOR), Bogor, 2012.

[53] S. Amira, "Pendugaan biomassa jenis Rhizophora apiculata B1 di hutan mangrove Batu Ampar Kabupaten Kubu Raya Kalimantan Barat," Institut Pertanian Bogor (IPB), Bogor, 2008.

[54] F. Fromard, H. Puing, E. Mougin, J.L. Betoulle, L. Cadamuro, "Structure, above-ground biomass and dynamics of mangrove ecosystems," Guiana, 1998.

[55] M.A. Tarlan, "Biomass estimation of Nyirih (Xylocarpus granatum) in primary mangrove forest in Batu Ampar, Kalimantan Barat," Institut Pertanian Bogor (IPB), Bogor, 2008. 